\title{
INTERROGATION OF EMPLOYEES AS AN UNFAIR LABOR PRACTICE*
}

EMPLOYERS frequently question an employee about his union attitudes, membership, or activities. ${ }^{1}$ Such questioning violates Section 8(a)(1) of the Taft-Hartley Act if it results in an interference with the worker's right to form, join, or assist labor organizations. ${ }^{2}$ The Courts of Appeals have generally held that interrogation does not violate the Act, ${ }^{3}$ unless so linked with other anti-union acts that it is part of a pattern of hostility directed against union activity. ${ }^{4}$ Some courts rationalize this "course of conduct" test by analogizing questioning to employer speechmaking. Since employer state-

*NLRB v. Jackson Press, Inc., 201 F.2d 541 (7th Cir. 1953).

1. The NLRB decided approximately 260 interrogation cases from Jan., 1949 to March, 1953.

2. Section 8 (a) (1) makes it an unfair labor practice for an employer "to interfere with, restrain, or coerce employees in the exercise of the rights guaranteed in section 7." 61 Stat. 140 (1947), 29 U.S.C. $\$ 158$ (a) (1) (Supp. 1952). Section 7 provides that "employees shall have the right to self-organization, to form, join, or assist labor organizations. . . " 61 Stat. 140 (1947), 29 U.S.C. \$157 (Supp. 1952).

Questions held illegal include those relating to (1) employees' union membership: I. B. S. Mfg. Co., 96 N.L.R.B. 1263, 1265 (1951); Dinion Coil Co., 96 N.L.R.B. 1435,1436 (1951) ; (2) attitude of employees toward the union: Minnesota Mining \& Mfg. Co., 81 N.L.R.B. 557, 558 (1949), enforcement granted, 179 F.2d 323, 326 (8th Cir. 1950) ; NLRB v. Consolidated Machine Tool Corp., 163 F.2d 376, 378 (2d Cir.), cert. denied, 332 U.S. 824 (1947) ; (3) union activities: NLRB v. Norfolk Southern Bus Corp., 159 F.2d 516, 518 (4th Cir. 1946), cert. denied, 330 U.S. 884 (1947) ; R. R. Donnelley \& Sons Co., 60 N.L.R.B. 635, 638 (1945), enforcement granted, 156 F.2d 416 (7th Cir. 1946) ; (4) voting intentions of employees: Artcraft Hosiery Co., 78 N.L.R.B. 333, 333-4 (1948); (5) identity of union organizers or active union members: Morristown Knitting Mills, 80 N.L.R.B. 731, 743 (1948).

3. At least four circuits have taken this view. See, e.g., NLRB v. England Bros., Inc., 201 F.2d 395 (1st Cir. 1952) ; NLRB v. Superior Co., 199 F.2d 39 (6th Cir. 1952); NLRB v. Arthur Winer, Inc., 194 F.2d 370 (7th Cir.), cert. denied, 344 U.S. 819 (1952); NLRB v. Montgomery Ward \& Co., 192 F.2d 160 (2d Cir. 1951); NLRB v. Tennessee Coach Co., 191 F.2d 546 (6th Cir. 1951) ; John S. Barnes Corp. v. NLRB, 190 F.2d 127 (7th Cir. 1951) ; Sax v. NLRB, 171 F.2d 769 (7th Cir. 1948).

Some circuits in interrogation cases have affirmed the Board without discussion. See, e.g., NLRB v. Hibriten Chair Co., 197 F.2d 1021 (4th Cir. 1952); NLRB v. Wytheville Knitting Mills, 175 F.2d 238 (3d Cir. 1949). For the Eighth Circuit's view, see note 30 infra.

4. See, e.g., Sax v. NLRB, 171 F.2d 769, 773 (7th Cir. 1948) (first case applying the "course of conduct" rule to interrogation); NLRB v. Superior Co., 199 F.2d 39, 43 (6th Cir. 1952). For discussion see Burstein, Free Speech for Employers, 1 Laron L.J. 425, 435-6 (1950).

5. "Such perfunctory, innocuous remarks and queries, standing alone . . . are insufficient to support a finding of a violation of Section 8(1). They come instead within the protection of free speech protected by the First Amendment to the Federal Constitution. The Supreme Court indicated that speech would not be sufficient to sustain a 
ments have long been allowed unless containing a threat or as part of a coercive course of conduct, ${ }^{6}$ these courts have permitted interrogation when the employer has not committed other unfair labor practices.

But despite the "course of conduct" rule in the Courts of Appeals, the National Labor Relations Board consistently holds that interrogation is per se a violation of Section $S(a)(1) .^{7}$ In the Board's view, the isolated act of questioning is sufficient to constitute an infraction; no other anti-union act by the employer need be shown. ${ }^{8}$ Neither the employer's motives in maling inquiries about union affairs, nor the coercive effects of a particular question are relevant under the NLRB test. ${ }^{3}$ However, despite its per se rule, the Board has occasionally allowed interrogation when some overriding necessity justified the questions or when the coercive effect of the questions was obviously de minimis. Thus, the NLRB has allowed questioning needed for the preparation of an employer's defense against an unfair labor practice charge. ${ }^{10}$ And questions asked with the consent of the union or casual interrogation by minor supervisors have been held too innocuous to warrant issuance of a remedial order. ${ }^{11}$

finding of a violation of Section $S(1)$ in NLRB v. Virginia Power Co., 314 U.S. 469 (1941). . . "Sax v. NLRB, 171 F.2d 769, 772 (7th Cir. 1948). See also NLRB v. Miontgomery Ward \& Co., 192 F.2d 160, 163 (2d Cir. 1951) (statements and questions treated together under the "free speech" section of the Taft-Hartley Act).

6. NLRB v. Virginia Electric \& Power Co., 314 U.S. 469 (1941) (first applieation of the "course of conduct" rule to employer speeches). For a discussion of subsequent cases on employer speechmaking, see Daykin, Enployers' Right of Free Sfrech in Irdustry under the NLRA, 40 ILL. L. REv. 185 (1945); Comment, 34 CALT. L. Rev. 415 (1946).

There is dispute in the cases over whether $\$ S(c)$, added to the Act in 1947, merely codified the existing "course of conduct" doctrine, or extended additional protection to speechmaking. For discussion of $\$ \$(c)$, see 2 TelLer, Lafor Disputes aid Conzctive BARganNing, $\$ \$ 398.105-7$ (1950) ; Cox, Some Aspects of the Labor Managencul Reletions Act, 61 HARv. L. REv. 1, 15-20 (1947); Note, 38 VA. L. REv. 1037, 1047-55 (1952).

7. See, e.g., Syracuse Color Press, Inc, 103 N.L.R.B. No. 26 (Mfarch 10, 1953); Washington Mills, 100 N.L.R.B. No. 25 (July 10, 1952); Calasieu Paper Co., 99 N.L.R.B. No. 122 (June 1S, 1952); Waynline, Inc., 81 N.L.R.B. 511 (1949).

8. See, e.g., Syracuse Color Press, Inc, 103 N.L.R.B. No. 26 (MIarch 10, 1953); Standard-Coosa-Thatcher Co., 85 N.L.R.B. 1358, 1360 (1949).

9. See, e.g., New Jersey Carpet Mills, Inc, 92 N.L.R.B. 604, 605 (1950); The F. C. Russell Co., 92 N.L.R.B. 206, 209 (1950).

10. See, e.g., Cold Spring Granite Co, 101 N.L.R.B. No. 154 (Dec. \&, 1952) ; May Department Stores Co., 70 N.L.R.B. 94 (1946), enforiement gronted, 162 F.2d 247 (8th Cir. 1947). But cf., Cummer-Graham Co., 90 N.L.R.B. 722 (1951) (questioning held illegal since interrogation could not have constituted preparation for defense); Joy Sill: Mills v. NLRB, 185 F.2d 732 (D.C. Cir. 1950) (questions must be relevant to charges of unfair labor practice to justify the risk of intimidation).

11. See, e.g., Sacony Vacuum Oil Co., 7S N.L.R.B. 1185, 1187 (1948) (questions asked with consent of the union and in the presence of union representatives); Capital Lumber Co., 103 N.L.R.B. No. 32 (Mrarch 2, 1953) (foreman's attitude while questioning appeared neutral and friendly); U.S. Gypsum Co., 93 N.L.R.B. 966,969 (1951) (questioning by a minor supervisor); Boston \& Lackport Block Co., 98 N.L.R.B. 696, 692 (1952) (questioning too innocuous to varrant remedial order). 
In the recent case of $N L R B v$. Jackson Press, Inc., ${ }^{12}$ the Seventh Circuit moved from the "course of conduct" rule towards the Board's per se doctrine. In this case the employer, during an organizational campaign, questioned two employees about their union sympathies. ${ }^{18}$ The court found that the employer did not have an anti-union background. ${ }^{14}$ The court also reversed a Board finding that the employer was guilty of refusing to bargain in good faith. ${ }^{15}$ Nevertheless, the Seventh Circuit held that the interrogation, standing alone, violated $8(\mathrm{a})(1) .{ }^{18}$ The court did not overrule earlier cases in its own circuit which, on facts similar to the Jackson case, had permitted questions under the "course of conduct" rule.17 Nor did the court indicate that it was adopting the per se rule against employer questioning. But in view of the fact that the "course of conduct" rule originated in the Seventh Circuit, ${ }^{18}$ the Jackson holding may become an influential precedent for the Board's rule.

Although no reasons for the Jackson holding were advanced by the court, the apparent acceptance of the Board's approach indicates judicial recognition that even isolated questions can frighten employees away from the union. Despite the plausible analogy to protected employer speechmaking, employees are more effectively coerced by questioning. ${ }^{10}$ Speechmaking requires the worker to listen to his employer's views but does not force him to reveal his own. Questioning, on the other hand, may extract information which is often used for subsequent reprisals. ${ }^{20}$ Even if the employer does not use the information to discriminate against union adherents, questions may be used

12. 201 F.2d 541 (7th Cir. 1953).

13. Id. at 545 .

14. Ibid.

15. Ibid.

16. Ibid.

17. The facts of a case decided just a year earlier are strikingly similar to Jackson: NLRB v. Arthur Winer, Inc., 194 F.2d 370 (7th Cir.), cert. denied, 344 U.S. 819 (1952). The employer, with no anti-union background, asked three employees during an organizational period about their attitude towards the union and about "what the union had to offer." The court overruled the Board and permitted the questions, which were unaccompanied by other hostile acts. See also John S. Barnes Corp. v. NLRB, 190 F.2d 127, 131 (7th Cir. 1951). The Jackson court dismissed the earlier cases by saying: "It is a close question under such decisions as N.L.R.B. v. Arthur Winer, Inc., . . . whether such inquiries standing alone were a violation of Sec. 8(a)(1)." NLRB v. Jackson Press, Inc., 201 F.2d 541, 545 (7th Cir. 1953).

18. See note 4 supra.

19. See notes $20-25$ infra.

20. In 67 of 80 interrogation cases before the Board from May, 1951 to March, 1953, some form of discriminatory practice occurred as a direct result of the inquiries. See cases indexed under "Questioning" in 29, 30 LAB. REL. REP. (Ref. Man.) and cases reported in 31 LAB. REL. REP. (Labor-Management). The usual form of reprisal was discharge. See, e.g., Stolle Corp., 103 N.L.R.B. No. 111 (March 26, 1953); Griffin Mfg. Co., 103 N.L.R.B. No. 79 (March 17, 1953) ; Dixie Terminal Co., 102 N.L.R.B. No. 101 (Feb. 18, 1953) ; Fuchs Baking Co., 102 N.L.R.B. No. 138 (Feb. 13, 1953). 
to induce fear of retaliation. ${ }^{21}$ This fear will be felt not only by the worker interrogated, but by all other employees who hear of the questioning. ${ }^{22}$ Especially in the insecure organizational period, the employer can make a seemingly innocent question suggest his displeasure with employees who support the union. ${ }^{23}$ Such questions may convey an imagined threat of reprisal, even if the employer intends neither the threat nor the reprisal.24 The coercive effect of interrogation is illustrated by the fact that employees sometimes lie in answer to an inquiry. ${ }^{25}$ Because of the suggestion inherent in a question, interrogation should be analogized, not to protected speechmaling, but to speeches containing a threat of reprisal. Such threatening speeches are clearly prohibited under $S(a)(1) ;^{26}$ the veiled threat which questions may communicate can be even more coercive. 27

If the "course of conduct" rule continues to be applied to questioning, an employer will be able to wage an effective anti-union campaign, especially if his plant is being organized for the first time. If the employer has not had to deal with a union before, his background with employees, for purposes of the "course of conduct" rule, will probably be friendly. By combining the right to make speeches and to interrogate, management could conduct a program of interviews with key workers, during which union sympathies could be examined and employer views firmly expressed. Thus without overt threats, influential employees might be swayed to an anti-union position or to at least a passive one. ${ }^{28}$

21. See, e.g., Syracuse Color Press, Inc, 103 N.L.R.B. No. 26 (March 10, 1953); Standard-Coosa-Thatcher Co., S5 N.L.R.B. 1358, 1361 (1949). Also see Morgan, Employer's Freedon of Speech and the IVagster Act, 20 TULANe L. REv. 469, 499 (1946).

22. See Peters, Cosrarunication Witurn Industry 26-8, 96-7 (1949).

23. For general discussion of the coercive effects of questioning, see Brigasice, TuEe SPOKEn WoRd 235 (1932). The suggestive power of a question may be espacially strong in the "superior-to-subordinate" relationship of employer and employee. See, c.g., Vatghan, Soctal Psychology 234, 722 (1948). For a discussion of the power of suggestion, see Gurnee, Elentents of Soctal Psychology 218-47 (1936).

24. A subordinate may attribute implications to the interrogation which were unintended by the employer. For analogous situations, see Vaugrass, op. cit. srspre note 23, at 238 .

25. In Syracuse Color Press, Inc, 103 N.L.R.B. No. 26 (Mrarch 10, 1953), two employees questioned about their membership in the union denied that they were members, although in fact they were. See also Standard-Coosa-Thatcher Co., 85 N.L.R.B. 1358, 1361 (1949).

26. See, e.g., NLRB v. Deena Artware, Inc, 198 F.2d 645, 650 (6th Cir. 1952); Collins Baking Co. v. NLRB, 193 F.2d 483 (5th Cir. 1951).

27. See GURNEe, op. cit. supros note 23, at 245.

28. The union has some protection against a campaign of interrogation and spechmaking, since the Board may invalidate a certification election which the union loses. This may be done even in the absence of a finding of an unfair labor practice. See, c.g., Cornell-Dubilier Electric Corp., 101 N.L.R.B. No. 209 (Jan. 19, 1953); General Shoe Corp., 97 N.L.R.B. 499 (1951). For a discussion of the limited value of this protection, see Note, Free Speech and Free Choice in Representation Elections: Effect of ToftHartley Act Section 8(c), 58 YaLE L.J. 165 (1948). 
Any business justification for employer questioning must be weighed against the danger of coercing employees. ${ }^{20}$ The Board's per se rule protects the worker without unduly burdening management. ${ }^{30}$ In addition, when the situation demands an exception to the overall rule, the Board as in the past will doubtless permit inquiries as a matter of necessity and fairness. ${ }^{31}$ And, while the line of illegality is shadily drawn under the "course of condtct" doctrine, the per se rule has the virtue of predictability.

29. For discussion of business necessity as a justification for interrogation, sec Note, 63 Harv. L. REv. 900, 901 (1950).

30. If an employer tried to extract such information by using spies, he would clearly violate the act. See, e.g., NLRB v. Public Service Co-ordinated Transport, 177 F.2d 119, 121 (3d Cir. 1949) ; NLRB v. 'Collins \& Aikman Corp., 146 F.2d 454, 455 (4th Cir. 1944). And one circuit has forbidden interrogation of an employee concerning his coworker's views on an analogy to "attempted surveillance." NLRB v. Minnesota Mining \& Mfg. Co., 179 F.2d 323, 326 (8th Cir. 1950). For the Board's similar position, sce Empire Pencil Co., 86 N.L.R.B. 1187, 1189 (1949) ; Standard-Coosa-Thatcher Co., 85 N.L.R.B. 1358, 1361 (1949).

31. See notes 10,11 supra. 